\title{
TEKNIK PENGENDALIAN PENYAKIT KHV PADA IKAN MAS (Cyprinus carpio) MELALUI MANIPULASI LINGKUNGAN DALAM SKALA LABORATORIUM
}

\author{
Iswari Ratna Astuti"), Tri Heru Prihadi"*), Hambali Supriyadi"), dan \\ Anang Hari Kristanto") \\ ") Pusat Penelitian dan Pengembangan Perikanan Budidaya \\ Jl. Ragunan 20, Pasar Minggu, Jakarta Selatan 12540 \\ E-mail: iswariastuti@yahoo.com \\ **) Balai Besar Penelitian dan Pengembangan Budidaya Laut \\ Jl. Br. Gondol, Kec. Gerokgak, Kab. Buleleng, Kotak Pos 140, Singaraja, Bali 81101
}

(Naskah diterima: 3 Agustus 2011; Disetujui publikasi: 14 September 2012)

\begin{abstract}
ABSTRAK
Koi herpes virus merupakan penyakit yang menyebabkan kerugian sangat besar bagi pembudidaya ikan mas. Oleh karena itu, perlu segera ada teknik pengendaliannya. Penelitian ini bertujuan untuk mendapatkan teknik pengendalian penyakit KHV pada benih ikan mas (Cyprinus carpio) melalui manipulasi suhu dan salinitas air. Ikan terinfeksi KHV dipelihara di dalam wadah pemeliharaan volume 45 liter, dengan kepadatan 15 ekor setiap wadah. Ikan uji berukuran 20-25 g/ekor. Penelitian menggunakan Rancangan Acak Kelompok dengan tiga ulangan. Perlakuan terdiri atas kombinasi suhu $\left(26^{\circ} \mathrm{C}-27^{\circ} \mathrm{C}, 29^{\circ} \mathrm{C}-30^{\circ} \mathrm{C}\right.$, suhu ruangan) dan salinitas $(0,4,8,12 \mathrm{ppt})$. Hasil penelitian menunjukkan bahwa suhu, salinitas, dan kombinasi suhu dengan salinitas berpengaruh nyata terhadap tingkat kematian ikan karena KHV. Tingkat kematian ikan terinfeksi $\mathrm{KHV}$ yang dipelihara pada suhu konstan $26^{\circ} \mathrm{C}-27^{\circ} \mathrm{C}$ dan $29^{\circ} \mathrm{C}-30^{\circ} \mathrm{C}$ terbukti lebih rendah dibanding yang dipelihara pada suhu ruang $\left(26^{\circ} \mathrm{C}-30^{\circ} \mathrm{C}\right)$. Kombinasi suhu air konstan pada $26^{\circ} \mathrm{C}-30^{\circ} \mathrm{C}$ dengan salinitas $4-8 \mathrm{ppt}$ adalah yang terbaik untuk pengendalian KHV.
\end{abstract}

KATA KUNCI: KHV, Cyprinus carpio, suhu, salinitas

ABSTRACT: Disease control strategy of KHV on common carp with environment manipulation in laboratory scale. By: Iswari Ratna Astuti, Tri Heru Prihadi, Hambali Supriyadi, and Anang Hari Kristanto

Koi herpes virus is a disease causing huge economic losses to carp farmers. Therefore, there is an urgent need for technical control of the disease. The aim of this experiment was to investigate technical control of KHV in common carp (Cyprinus carpio) through manipulation of water temperature and salinity. KHV-infected fish were reared in $45 \mathrm{~L}$ aquaria with density of 15 fish/aquarium. The size of the fish is 20-25 g/fish. The experiment used Random Design Group with three replications. The treatments consist of combination of water temperatures $\left(26^{\circ} \mathrm{C}-27^{\circ} \mathrm{C}, 29^{\circ} \mathrm{C}-30^{\circ} \mathrm{C}\right.$, room temperature) and salinities $(0,4,8,12$ ppt). The result of the experiment shows that temperature, salinity, and combination of temperature and salinity had significantly different effect on mortality of fish due to KHV. Mortality of KHV-infected fish reared in a constant water temperature of $26^{\circ} \mathrm{C}-27^{\circ} \mathrm{C}$ and $29^{\circ} \mathrm{C}-30^{\circ} \mathrm{C}$ proved to be lower than the fish reared in room temperature $\left(26^{\circ} \mathrm{C}-30^{\circ} \mathrm{C}\right)$. Combination of constant water 
temperatures at $26^{\circ} \mathrm{C}-30^{\circ} \mathrm{C}$ and salinity of 4-8 ppt provide the best control strategy for KHV.

\section{KEYWORDS: KHV, Cyprinus carpio, temperature, salinity}

\section{PENDAHULUAN}

Ikan mas (Cyprinus carpio) merupakan jenis ikan air tawar yang menjadi primadona kegiatan budidaya ikan di air tawar. Teknik pembudidayaannya relatif mudah, tetapi seringkali para pembudidaya ikan dihadapkan pada masalah kematian ikan yang disebabkan oleh penyakit. Penyakit yang menyerang ikan mas umumnya disebabkan oleh virus, bakteri, jamur, protozoa, dan cacing.

Salinitas adalah tingkat kadar garam terlarut dalam air. Satuan salinitas umumnya dalam bentuk ppt. Air tawar memiliki salinitas $0 \mathrm{ppt}$, air payau memiliki salinitas 1-30 ppt, dan air laut/asin memiliki salinitas di atas 30 ppt.

Garam dapat dipergunakan sebagai obat di dalam pengendalian beberapa jenis penyakit ikan dan sudah dibuktikan terhadap penyakit yang disebabkan oleh bakteri, jamur, maupun parasit (Anonim, 2010). Garam juga dapat menurunkan tingkat racun terutama $\mathrm{NH}_{3}$ (amonia) dan $\mathrm{NO}_{2}$ (nitrit) yang dihasilkan oleh suatu sistem budidaya.

Ikan mas tergolong ikan air tawar, namun seringkali ditemukan di perairan payau atau di muara sungai yang bersalinitas 25-30 ppt. Hasil pengamatan yang dilakukan oleh Sukmana (2009) menunjukkan bahwa ikan mas masih dapat bertahan hidup pada kisaran salinitas 9 ppt.

Koi Herpes Virus (KHV) merupakan penyakit virus ganas yang menyebabkan kematian massal pada ikan mas dan ikan koi. Virus ini dapat menyerang ikan mas dan ikan koi pada berbagai tingkatan umur, namun berdasarkan uji kohabitasi, ikan ukuran benih lebih rentan dibandingkan dengan ikan ukuran induk. Penyakit KHV dapat menyebabkan kematian massal hingga 80\%-100\% dari populasi ikan mas dan umumnya terjadi pada fluktuasi suhu air $22^{\circ} \mathrm{C}-27^{\circ} \mathrm{C}$ (Perelberg et al., 2003).

Kasus KHV umumnya sangat terkait dengan kondisi lingkungan perairan. KHV menjadi aktif ketika kondisi stres meningkat, akibat dari tingkat populasi yang tinggi, kekurangan oksigen, kualitas makanan yang rendah, kualitas air yang tidak memadai, atau polusi lainnya sehingga daya tahan tubuh melemah dan virus kembali menyerang. Perubahan suhu air pemeliharaan adalah menjadi penyebab stres yang sering terjadi.

Gilad et al. (2003) menyatakan bahwa faktor yang paling definitif mempengaruhi virulensi KHV adalah suhu air. Menurut OATA (2001), kasus kematian ikan akibat KHV umumnya terjadi pada kisaran suhu antara $18^{\circ} \mathrm{C}-27^{\circ} \mathrm{C}$, tidak terjadi kematian ikan pada suhu di bawah $18^{\circ} \mathrm{C}$ dan tidak ada laporan kasus KHV pada suhu air di atas $30^{\circ} \mathrm{C}$.

Di Indonesia, KHV secara umum menginfeksi ikan mas yang ada di Jawa dan luar Jawa dengan benih yang berasal dari Jawa. Hal ini mengakibatkan banyak pembudidaya yang mengalami kerugian besar, pada akhirnya beralih pada budidaya komoditas Iain. Salah satu usaha pemerintah dalam mengantisipasi kerugian yang lebih besar akibat serangan KHV adalah pelarangan peredaran ikan mas dari daerah yang terserang KHV ke daerah lain yang belum terserang. Upaya lain yang dapat dilakukan adalah melalui uji PCR secara dini terhadap ikan mas yang akan didistribusikan ke daerah lain.

Akhir-akhir ini, para pembudidaya ikan terutama di sepanjang pantai Utara Jawa Barat mulai membudidayakan ikan mas di tambak yang berisi air payau, sebagai pengganti udang dan ikan bandeng. Sejauh ini usaha tersebut menguntungkan, bahkan ikan mas dari tambak air payau lebih diminati pembeli karena dagingnya yang padat dan rasanya lebih gurih (Karyono, 2009). Bahkan, ikan mas yang dibudidayakan di air payau belum pernah dilaporkan terserang penyakit KHV. Hal ini diduga pada kondisi salinitas tersebut merupakan kondisi yang kurang memungkinkan bagi berkembangbiaknya virus KHV. Untuk itu, perlu dilakukan penelitian terhadap pengaruh suhu yang dikombinasikan dengan salinitas untuk mengetahui pengaruh kedua faktor tersebut terhadap infeksi KHV pada ikan mas.

Tujuan penelitian adalah untuk mendapatkan informasi tentang pengaruh suhu dan salinitas air terhadap infeksi penyakit KHV pada ikan mas. 


\section{BAHAN DAN METODE}

Ikan uji yang digunakan adalah benih ikan mas yang berasal dari dua lokasi yang berbeda. Kelompok pertama adalah ikan mas bebas KHV berdasarkan hasil pemeriksaan dengan metode PCR pada sampel ikan berukuran 20-25 g/ekor, diperoleh dari pembudidaya ikan mas di Sukamandi. Kelompok kedua adalah ikan mas positif terinfeksi KHV yang diperoleh dari pembudidaya ikan KJA di Waduk Cirata, Jawa Barat. Konfirmasi status kelompok ikan positif atau negatif terhadap infeksi KHV tersebut dilakukan sebelum penelitian berlangsung melalui deteksi secara laboratoris menggunakan teknik Polymerase Chain Reaction (PCR) menurut metode yang dikembangkan oleh Gray et al. (2002).

Penelitian dilakukan di Pusat Penelitian dan Pengembangan Perikanan Budidaya Jakarta. Penelitian menggunakan wadah pemeliharaan sebanyak 36 buah, berupa bak plastik volume 60 liter yang diisi air sebanyak 45 liter. Wadah pemeliharaan dilengkapi dengan aerasi. Kepadatan ikan tiap wadah adalah 15 ekor. Pakan komersial digunakan dalam penelitian ini dengan frekuensi pemberian pakan 2 kali sehari sebanyak $2 \%$ dari bobot biomassa per hari.

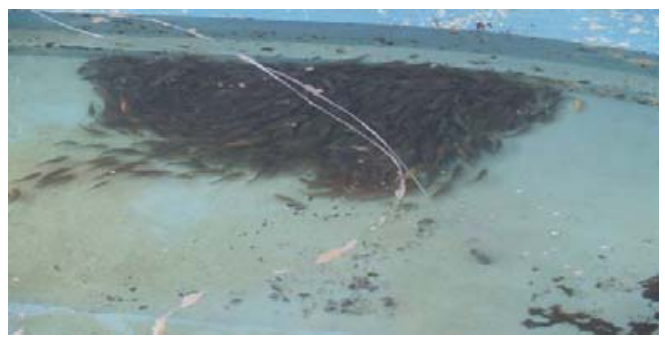

Gambar 1. Ikan mas sehat asal Sukamandi

Figure 1. Healthy fish from Sukamandi

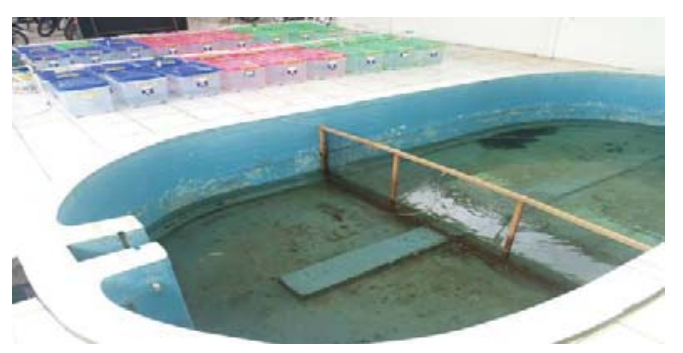

Gambar 3. Bak kohabitasi

Figure 3. Cohabitation tank
Penelitian dilaksanakan dengan menggunakan Rancangan Acak Kelompok (Steel \& Torrie, 1993) dengan tiga kali ulangan. Sebagai perlakuan adalah kombinasi suhu $\left(26^{\circ} \mathrm{C}-27^{\circ} \mathrm{C}\right.$, $29^{\circ} \mathrm{C}-30^{\circ} \mathrm{C}$, dan suhu ruangan dengan kisaran $\left.26^{\circ} \mathrm{C}-30^{\circ} \mathrm{C}\right)$ serta salinitas $(0,4,8,12 \mathrm{ppt})$. Pada kelompok perlakuan suhu $26^{\circ} \mathrm{C}-27^{\circ} \mathrm{C}$ dan suhu $29^{\circ} \mathrm{C}-30^{\circ} \mathrm{C}$ dilakukan dengan cara menempatkan wadah percobaan dalam ruang laboratorium yang dilengkapi dengan alat pemanas air (water heater merk Atman), masingmasing satu buah per wadah percobaan. Pada kelompok perlakuan salinitas 4, 8, dan $12 \mathrm{ppt}$ dilakukan dengan cara mencampurkan garam sesuai dengan perlakuan salinitas. Pengecekan salinitas menggunakan refraktometer.

Ikan uji yang terinfeksi KHV diperoleh dengan cara kohabitasi dari kelompok ikan mas bebas KHV dengan kelompok ikan mas positif terinfeksi KHV dalam wadah yang disekat kawat kasa (screen) selama enam hari pada suhu air $25^{\circ} \mathrm{C}-27^{\circ} \mathrm{C}$. Setelah proses kohabitasi, ikan uji yang telah menjadi positif terinfeksi KHV dipelihara pada wadah pemeliharaan sesuai dengan perlakuan.

Pengamatan terhadap tingkah laku, gejala klinis, dan mortalitas ikan uji dilakukan setiap hari hingga akhir percobaan. Pengujian di-

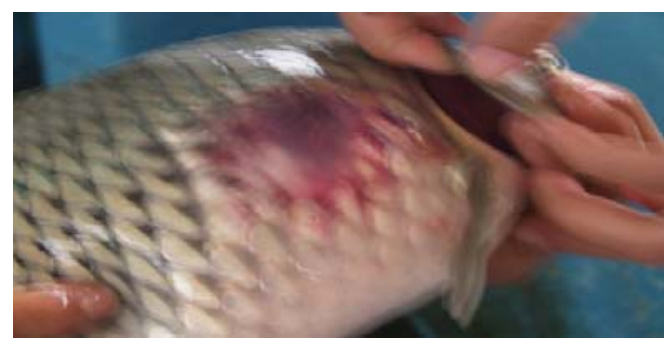

Gambar 2. Ikan mas sakit asal Waduk Cirata

Figure 2. KHV infected fish from Cirata Reservoir's

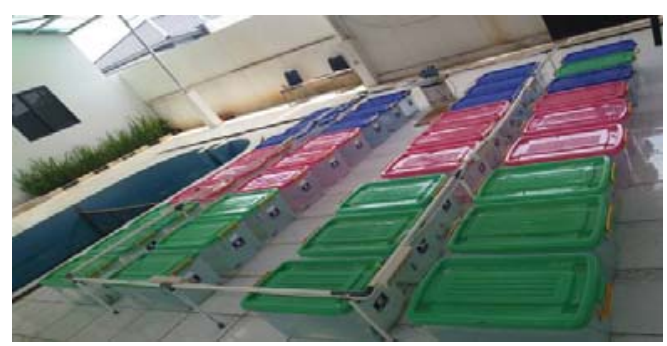

Gambar 4. Akuarium wadah perlakuan

Figure 4. Experimental aquaria 
lakukan selama dua minggu. Pengambilan sampel untuk diagnosa PCR juga dilakukan pada akhir pengamatan.

Pengukuran terhadap kualitas air dilakukan pada setiap wadah pemeliharaan meliputi suhu dengan menggunakan termometer min-max, $\mathrm{pH}$ (pH-meter), dan DO (DO-meter).

\section{HASIL DAN BAHASAN}

Ikan mas sehat yang berasal dari pembudidaya ikan mas di daerah Sukamandi dikohabitasi dengan ikan mas sakit yang berasal dari Waduk Cirata, Jawa Barat di bak beton selama 6 hari pada kisaran suhu $25^{\circ} \mathrm{C}$ $27^{\circ} \mathrm{C}$. Suhu tersebut termasuk dalam rentang suhu optimal (permissive temperature) bagi perkembangbiakan virus $\mathrm{KHV}$ yaitu $18^{\circ} \mathrm{C}-28^{\circ} \mathrm{C}$, sehingga ikan yang sehat bisa tertular ikan yang sakit pada kondisi suhu tersebut. Berdasarkan hasil pengamatan mulai hari ke-5

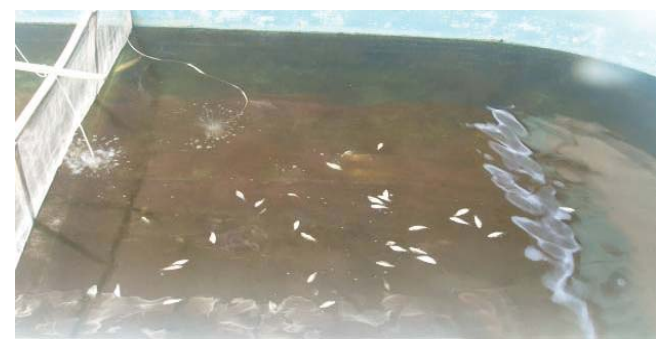

Gambar 5. Ikan mati (hari ke-6 kohabitasi)

Figure 5. Dead fish at 6 days post cohabitation kohabitasi sudah ditemukan beberapa ikan yang sakit dan akhirnya banyak yang mati, demikian juga pada pengamatan hari ke- 6 . Sampel ikan yang sakit menunjukkan gejala klinis terserang virus KHV yaitu insang berwarna pucat dan muncul bercak putih pada lembar insang, gerakannya lambat, kesulitan bernafas, dan akhirnya mati. Hal ini sesuai dengan pernyataan OATA (2001) bahwa gejala klinis yang nampak pada ikan yang terinfeksi KHV adalah berupa kerusakan pada insang berwarna pucat yang selanjutnya muncul bercak putih (white patch) pada filamen insang dan akhirnya insang membusuk (gill necrosis), pergerakan ikan lemah, megap-megap, terjadi pendarahan, dan kulit melepuh, serta terjadi kematian massal dalam jangka waktu 1-7 hari.

Uji PCR terhadap ikan uji setelah proses kohabitasi selama 6 hari menunjukkan ikan positif terinfeksi KHV (Gambar 7). Selanjutnya

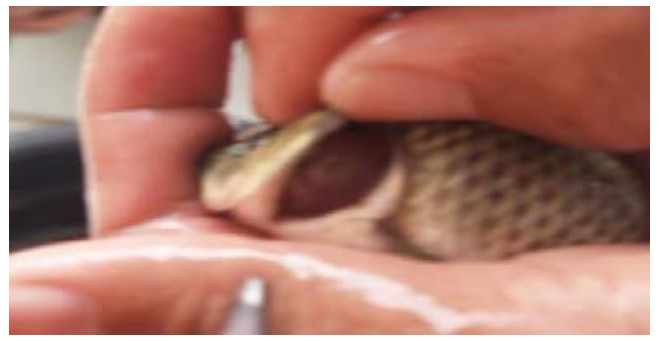

Gambar6. Insang ikan menunjukkan infeksi $\mathrm{KHV}$

Figure 6. Gill of carp showing KHV infection

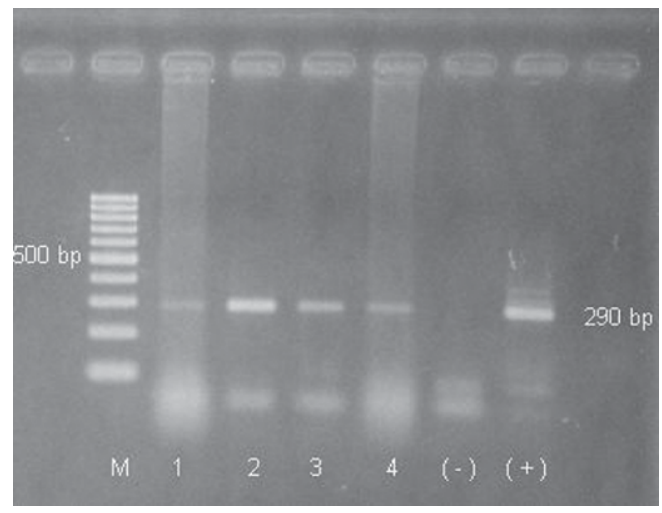

Keterangan (Remark):

M : Marker

1-4: Ikan mas sakit (Diseased fish)

$(-)$ : Kontrol negatif (Negative control)

(+) : Kontrol positif (Positif control)

Gambar 7. Hasil uji PCR terhadap sampel ikan percobaan menunjukkan bahwa ikan (1-4) terinfeksi KHV

Figure 7. Results of PCR test for experimental fish showed that the fish (Lane 1-4) are infected with KHV 
pada hari ke- 6 masa kohabitasi, sebelum terjadi kematian massal pada ikan yang dikohabitasi, ikan yang sudah terinfeksi segera dipindahkan ke wadah perlakuan yang sudah dilengkapi dengan aerator dan alat pemanas air (water heater).

Hasil pengamatan pada akhir percobaan terhadap semua perlakuan menunjukkan bahwa ikan tampak aktif bergerak, respons terhadap pakan yang diberikan bagus dan permukaan tubuh tidak menunjukkan adanya luka maupun infeksi sekunder. Diagnosa PCR terhadap ikan sampel yang masih bertahan hidup setelah akhir percobaan juga dilakukan dengan hasil negatif (Gambar 8).

Hasil pengamatan terhadap jumlah mortalitas ikan selama 14 hari percobaan disajikan pada Gambar 9.

Dari semua perlakuan pada Gambar 9 dapat dilihat bahwa mortalitas ikan tertinggi (60\%) diperoleh pada kelompok uji pada suhu ruangan $\left(26^{\circ} \mathrm{C}-30^{\circ} \mathrm{C}\right)$ dengan salinitas $0 \mathrm{ppt}$. Pada perlakuan kisaran suhu $26^{\circ} \mathrm{C}-27^{\circ} \mathrm{C}$, mortalitas tertinggi pada salinitas 0 ppt $(46,7 \%)$, sedangkan pada kisaran suhu $29^{\circ} \mathrm{C}-30^{\circ} \mathrm{C}$ mortalitas tertinggi masing-masing pada salinitas 0 ppt dan 12 ppt yaitu sebesar 13,3\%. Adapun mortalitas ikan pada salinitas $4 \mathrm{ppt}$ dan 8 ppt pada semua perlakuan suhu adalah kurang dari $13,3 \%$. Angka mortalitas yang diperoleh ternyata lebih rendah dibandingkan dengan hasil penelitian Taukhid et al. (2005) tentang pengaruh suhu air terhadap patogenisitas KHV pada skala laboratorium, yaitu pada kisaran suhu air $22^{\circ} \mathrm{C}-26^{\circ} \mathrm{C}$ persentase mortalitas kumulatif yang terjadi sangat tinggi yaitu mencapai $94 \%$, pada kisaran $26^{\circ} \mathrm{C}-30^{\circ} \mathrm{C}$ sebesar $71 \%$, dan pada kisaran $30^{\circ} \mathrm{C}-34^{\circ} \mathrm{C}$ sebesar $32 \%$.

Jika dibandingkan antara ketiga perlakuan suhu, maka dapat dilihat bahwa jumlah mortalitas ikan tertinggi dicapai pada kelompok suhu ruangan. Analisis ragam menunjukkan bahwa perlakuan suhu yang berbeda berpengaruh nyata terhadap mortalitas ikan akibat infeksi penyakit KHV.

Mortalitas ikan pada kelompok perlakuan suhu ruangan lebih tinggi dibanding pada perlakuan suhu konstan $26^{\circ} \mathrm{C}-27^{\circ} \mathrm{C}$ dan $29^{\circ} \mathrm{C}$ $30^{\circ} \mathrm{C}$, kemungkinan disebabkan oleh fluktuasi suhu yang besar yaitu pada kisaran $26^{\circ} \mathrm{C}-30^{\circ} \mathrm{C}$ sehingga dapat mempercepat berkembangnya virus KHV dan berakibat pada tingginya jumlah ikan yang mati.

Untuk keempat perlakuan salinitas, jumlah rata-rata ikan yang mati paling banyak ditemukan pada salinitas 0 ppt dibandingkan dengan salinitas 4,8 , dan 12 ppt. Hal ini kemungkinan disebabkan karena pada salinitas 0 ppt tidak mengandung kadar garam yang diduga dapat memberikan daya tahan ikan mas terhadap penyakit yang dideritanya sehingga ikan banyak yang mati. Analisis ragam menunjukkan bahwa salinitas memberikan pengaruh yang nyata terhadap ketahanan ikan yang terserang KHV. Hal ini sesuai dengan

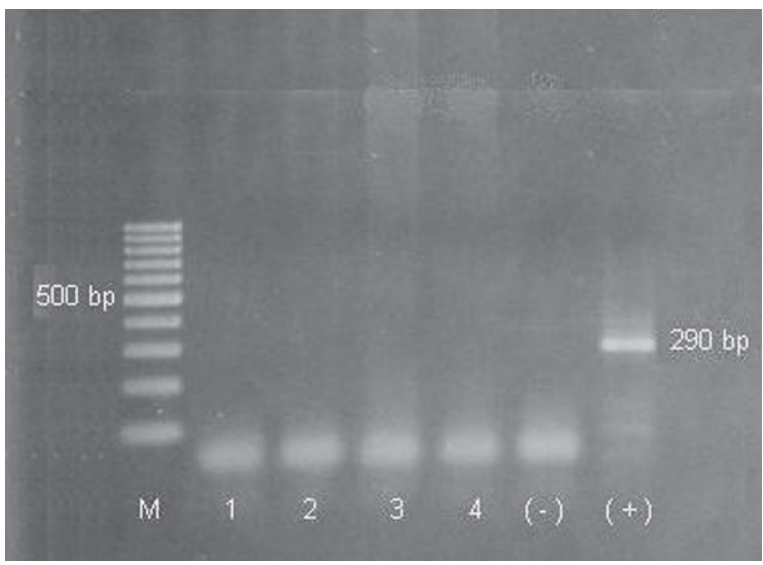

Keterangan (Remark):

M : Marker

1-4: Ikan mas sakit (Diseased fish)

$(-)$ : Kontrol negatif (Negative control)

(+) : Kontrol positif (Positif control)

Gambar 8. Hasil uji PCR terhadap ikan mas percobaan setelah dua minggu perlakuan menunjukkan bahwa ikan tidak terinfeksi KHV

Figure 8. Result of PCR test of experimental fish at two weeks post treatment showing that the fish were not infected with KHV 


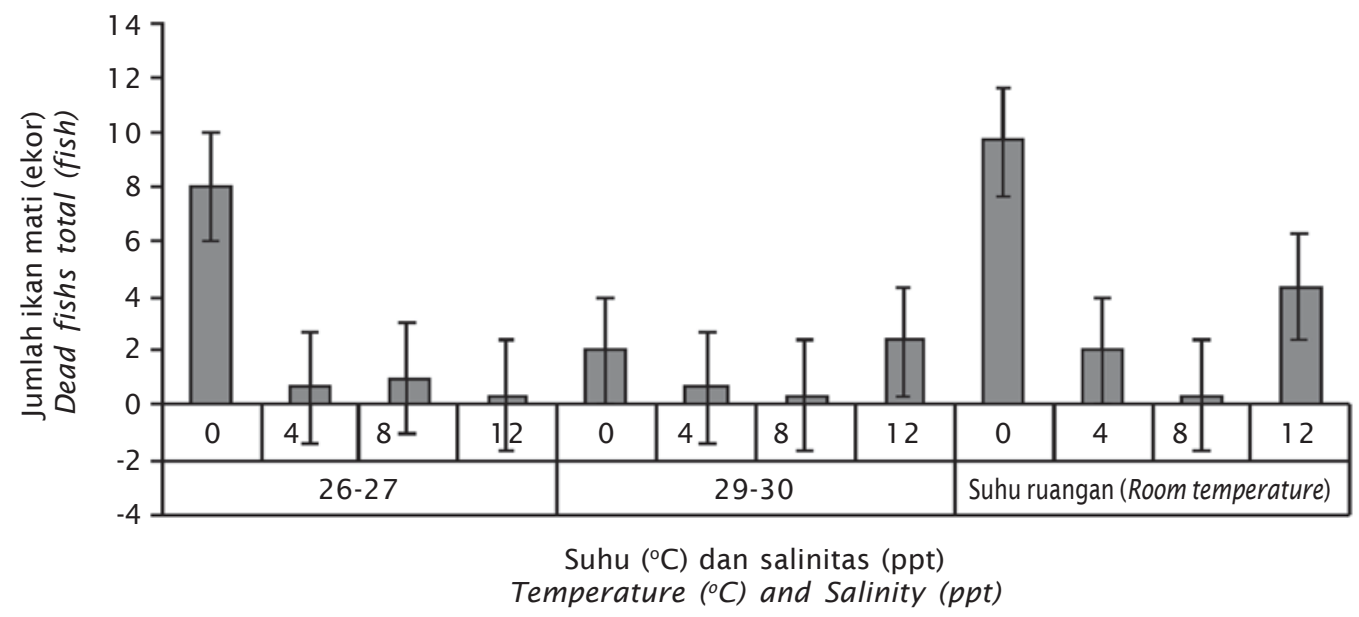

Gambar 9. Mortalitas ikan mas pada setiap perlakuan

Figure 9. Mortality of common carp in each treatment

pernyataan Vangel (2006) bahwa salinitas 3 ppt dapat mengurangi tingkat kematian ikan koi yang positif terserang KHV.

Penelitian Praseno et al. (2009) tentang ketahanan beberapa strain ikan mas yang dipelihara selama 34 hari pada salinitas 4,8 , dan 12 ppt menunjukkan sintasan yang berbeda yaitu $71,25 \%$ (4 ppt), 66,25\% (8 ppt), dan $26,25 \%$ (12 ppt). Namun sampai saat ini belum pernah dilaporkan mengenai pengaruh salinitas dalam menyembuhkan virus KHV yang menyerang ikan mas. Pemberian garam pada pemeliharaan ikan mas yang terserang KHV diduga dapat menghambat proses pertumbuhan virus, yaitu dengan mempengaruhi senyawa-senyawa yang bisa menekan proses replikasi virus. Pada proses replikasi virus, diperlukan sintesis asam nukleat dan protein mulai dari awal sampai akhir infeksi. Jika proses pembentukan DNA dihambat, maka proses pembentukan protein juga menjadi terhambat. Oleh karena itu, pembentukan virus baru menjadi terhambat.

Pengembangan vaksin anti virus untuk pencegahan infeksi virus belum mencapai hasil seperti yang diharapkan. Obat anti virus yang dapat menghambat atau membunuh virus juga akan dapat merusak sel inang tempat virus itu berada. Pencegahan penyakit virus adalah dengan meningkatkan sistem kekebalan tubuh (Anonim, 2006).

Seperti halnya infeksi virus lainnya, ikan mas yang terinfeksi KHV berpotensi sebagai karier virus. Dengan demikian, KHV dapat menginfeksi ikan yang terlihat sehat. KHV menjadi aktif kembali ketika ikan dalam kondisi stres sehingga daya tahan tubuh melemah yang mengakibatkan virus kembali menginfeksi.

Salinitas diduga mempengaruhi ketahanan ikan mas yang terserang KHV. Hal ini kemungkinan karena di dalam kehidupan ikan, garam berfungsi untuk menurunkan tingkat stres osmotik dengan mengurangi gesekan osmotik antara tubuh ikan dan sekelilingnya, dengan kata lain tubuh ikan serasa lebih ringan dan lebih mudah berenang, sehingga mengurangi daya/tenaga yang dibutuhkan untuk bergerak.

Pemberian garam dengan dosis yang tepat akan membantu menyeimbangkan kembali proses osmoregulasi dan memicu daya tahan tubuh ikan terhadap penyakit yang dideritanya (Anonim, 2009) sehingga ikan tetap dapat bertahan hidup dan mempunyai kesempatan untuk memulihkan dirinya dari luka dan penyakitnya. Dosis pemberian garam tidak boleh lebih tinggi dari kadar garam dalam darah ikan karena apabila hal ini terjadi air akan keluar dari tubuh ikan, dan garam akan masuk ke dalam darah yang berakibat ikan menjadi terdehidrasi dan akhirnya mati.

Hasil yang sama juga ditemukan pada perlakuan kombinasi suhu dengan salinitas. Analisis ragam menunjukkan bahwa suhu dan salinitas sangat berpengaruh nyata terhadap ketahanan tubuh ikan yang terserang KHV $(\mathrm{P}<0,05)$. 
Tabel 1. Kualitas air pada awal dan akhir penelitian

Table 1. Water quality at the beginning and end of the experiment

\begin{tabular}{llc}
\multicolumn{1}{c}{$\begin{array}{c}\text { Parameter } \\
\text { Parameters }\end{array}$} & $\begin{array}{c}\text { Nilai rata-rata } \\
\text { Average value }\end{array}$ \\
\hline Suhu (Temperature) $\left({ }^{\circ} \mathrm{C}\right)$ & & $26-30$ \\
$\mathrm{pH}$ & 8.11 (Awal penelitian) & 7.45 (Akhir penelitian) \\
& 8.11 (Initial research) & 7.45 (Final research) \\
$\mathrm{DO}(\mathrm{mg} / \mathrm{L})$ & 11.45 (Awal penelitian) & 10.80 (Akhir penelitian) \\
& 11.45 (Initial research) & 10.80 (Final research) \\
\hline
\end{tabular}

Secara keseluruhan, hasil pengujian menunjukkan bahwa suhu, salinitas, serta kombinasi suhu dengan salinitas berpengaruh nyata terhadap daya tahan ikan yang terserang virus KHV. Diharapkan, di masa depan perlakuan tersebut dapat digunakan untuk mengurangi tingkat kematian ikan dari serangan KHV.

Pengukuran terhadap kualitas air dalam wadah pemeliharaan disajikan pada Tabel 1 .

Dari Tabel 1 dapat diketahui bahwa kualitas air pemeliharaan masih memenuhi kriteria untuk budidaya ikan. Menurut Boyd (1990), suhu optimum untuk kehidupan ikan adalah $25^{\circ} \mathrm{C}-30^{\circ} \mathrm{C}$; $\mathrm{pH}$ optimal 5,5-9,0; dan oksigen terlarut untuk budidaya ikan di atas $5 \mathrm{mg} / \mathrm{L}$.

\section{KESIMPULAN}

1. Suhu, salinitas, serta kombinasi suhu dengan salinitas berpengaruh nyata terhadap pengendalian penyakit KHV.

2. Pengendalian KHV dengan suhu konstan antara $26^{\circ} \mathrm{C}-27^{\circ} \mathrm{C}$ dan $29^{\circ} \mathrm{C}-30^{\circ} \mathrm{C}$; salinitas 4-8 ppt; serta kombinasi suhu $26^{\circ} \mathrm{C}-27^{\circ} \mathrm{C}$ dan $29^{\circ} \mathrm{C}-30^{\circ} \mathrm{C}$ dengan salinitas $4-8 \mathrm{ppt}$ adalah terbaik dalam menekan mortalitas ikan mas (menghambat perkembangan KHV).

\section{SARAN}

Agar dikaji tindak lanjut pengaruh salinitas terhadap budidaya ikan mas dengan aplikasi di lahan tambak untuk pendederan dan pembesaran.

\section{UCAPAN TERIMA KASIH}

Riset ini dibiayai oleh APBN dana bantuan sosial DIPA Direktorat Penelitian dan Pengabdian kepada Masyarakat, Direktorat Jenderal Pendidikan Tinggi, Departemen
Pendidikan Nasional tahun 2009. Penulis mengucapkan terima kasih kepada Saudara/i Setiyadi, Tiara Dwi Ratih, Erfina Savitri, Iwan Malhani, Fitria Ariestyani, Dra. Koesharyani, dan Lila Gardenia, M.Si. yang telah membantu pelaksanaan kegiatan baik di lapangan maupun di laboratorium, dan hingga terselesainya tulisan ini. Ucapan terima kasih juga penulis sampaikan kepada Dr. Agus Sunarto atas kesediaan mengoreksi tulisan ini.

\section{DAFTAR ACUAN}

Anonim. 2006. Anti virus. http://www. medicastore.com.

Anonim. 2009. Pengobatan koi, obat, dan dosis. http://www.Cempakakoifarm.blogspot. com.

Anonim. 2010. Kualitas air dan filter yang dibutuhkan dalam pemeliharaan koi yang baik. http://zh-hk.facebook.com.

Boyd, C.E. 1990. Water Quality in Ponds for aquaculture. Alabama Agricultural Experiment Station. Auburn University, Alabama, $477 \mathrm{pp}$.

Gilad, Yun, O.S., Adkison, M.A., Way, K., Willits, N.H., Bercovier, H., \& Hedrick, R.P. 2003. Molecular comparison of isolates of an emerging fish pathogen, koi herpes virus, and the effect of water temperature on mortality of experimentally infected koi. Journal of General Virology, 84(2): 661-668.

Gray, W.L., Mullis, L., La Patra, S.E., Groff, J.M., \& Goodwin, A. 2002. Detection of koi herpesvirus DNA in tissues of infected fish. Journal of Fish Disease, 25: 171-178.

Karyono. 2009. Petambak beralih ke budidaya ikan mas dan gurame. Harian Pikiran Rakyat. Selasa, 28 April 2009.

Ornamental Aquatic Trade Association (OATA). 2001. Koi Herpes Virus (KHV). OATA, Westbury, Wilts, UK. 
Perelberg, A., Smirnov, M., Hutoran, M., Diamant, A., Bejerano, Y., \& Kotler, M. 2003. Epidemiological description of a new viral disease afflicting cultured Cyprinus carpio in Israel. The Israeli Journal of Aquaculture, 55(1): 5-12.

Praseno, O. 2009. Uji ketahanan salinitas beberapa strain ikan mas yang dipelihara di akuarium. Laporan Hasil Riset. Pusat Riset Perikanan Budidaya, $20 \mathrm{hlm}$.

Steel, R.G.D. \& Torrie, J.H. 1993. Prinsip dan Prosedur Statistika. Suatu Pendekatan Biometrik. Edisi Kedua. PT Gramedia Pustaka Utama. Jakarta, $748 \mathrm{hlm}$.
Sukmana. 2009. Pengaruh salinitas terhadap ikan mas. Laporan Praktikum. http:// wahyusukmana.blogspot.com.

Taukhid, Sumiati, T., \& Koesharyani, I. 2005. Pengaruh suhu air dan total bahan organik terlarut terhadap patogenisitas Koi Herpes Virus pada ikan mas (Cyprinus carpio). Strategi Pengelolaan dan Pengendalian Penyakit KHV, Suatu Upaya Pemecahan dalam Pembudidayaan Ikan Air Tawar. Pusat Riset Perikanan Budidaya, Jakarta, 105 hlm.

Vangel, M. 2006. Do you really know KHV ? http://www.mvangel.com. 